УДК 321.01

DOI: https://doi.org/10.21564/2663-5704.50.233897

Martsikhiv Khrystyna Romanivna, $\mathrm{PhD}$ in Pedagogy, Associate Professor of Foreign Language Department,

Lviv Polytechnic National University, Ukraine e-mail:khrystyna.hrytsko@gmail.com

ORCID ID: 0000-0003-4637-6604

Horbachova Liliia Yevgenivna, student,

Lviv Polytechnic National University, Ukraine

e-mail: liliagorbachova@gmail.com

ORCID ID: 0000-0002-3203-5350

\title{
THE CONCEPT OF CIVIL SOCIETY, ITS FORMATION IN UKRAINE, FUNCTIONS AND FEATURES
}

The concept of «civil society» in modern political science is given. The relevance of its theoretical and practical aspects which is caused by the obvious increase the role of ordinary citizens and their voluntary associations in all spheres of human society: economic, political, social, spiritual, is analyzed. The successes of public organizations and movements of people of good will in the field of detente of international tensions, in providing assistance to peoples affected by natural disasters, catastrophes and other social unrest are widely known. It was established that the basis of victories is the development of civil society, high activity of citizens and their voluntary associations. This is achievable only in a sufficiently developed civil society. It has been proved that success comes where the business activity of citizens and the non-governmental structures they create increases, state intervention in economic, social and spiritual life is limited, where civil society develops and improves. The theoretical and applied aspects of the phenomenon of civil society are comprehended through a theoretical analysis of the concept of civil society in the history of socio-philosophical and political thought, from Plato and Aristotle to the views of modern researchers. It is emphasized that civil society is a type of social system, the hallmark of which is the real multi-subjectivity of economic, social, cultural and political life. The formation and development of civil society in Ukraine during the years of independence is analyzed. It is proved that the formation of civil society is manifested in the formation of its institutions - voluntary public associations, public movements, trade unions, independent media, public opinion as a social institution, elections and referendums as a means of public expression and protection of public-dependent interests. judicial and law enforcement systems, etc. The peculiarities of the interaction of civil society and the rights' state are substantiated.

Keywords: civil society, the concept of civil society, state power, political party, welfare state, state of rights. 
Problem setting. Civil society is one of the key categories of modern political science. The processes that take place in it largely determine the content of the policy and the directions of its implementation. The path to civil society, the development of its concept, its own formation and development are complex and long-term. This article reveals issues that will help to understand the nature, structure, features and problems of civil society in modern democracies. Today, civil society is often defined as the opposite, the counterweight to the state. After all, with the advent of the state there is a kind of bifurcation of elements of public life into purely civil and state. However, the purely independent life of civil society is almost non-existent, in most of its manifestations it is intertwined with the life of the state, and the institutions themselves are designed to solve or facilitate complex state tasks, including the implementation of state-guaranteed constitutional rights and freedoms [1, p. 299-300]. There is no unambiguous relationship between the existence of the state and the presence or absence of civic principles in society.

Analysis of recent research and publications. At different times, the problem of civil society, the rule of law, the interaction between them has attracted the attention of scientists and politicians. In the historical context, we can point to successes in the study of these phenomena. Aristotle and N. Machiavelli made a significant contribution to their research. J.-J. Rousseau, G. W. F. Hegel, J. Locke and other researchers. The methodological basis of the work is the achievement of world socio-political thought, which includes the works of progressive political scientists, sociologists, philosophers, educators; state documents, legislative acts. There is a noticeable success in the study of various aspects of social consciousness and its forms, such as political, economic, legal and so on. This problem includes the works of V. Babkin, I. Dzyubko, L. Egholm, G. Fine, L. Herasina, L. Kaspersen, V. Korniyenko, O. Nesterenko, S. Ryabov, V. Stepanenko, M. Trebin, V. Yablonskyi and others [2-9]. Theoretical and methodological issues of the functioning and essence of political consciousness, its structure and relationship with other forms of social consciousness are covered in the works of O. Babkina, V. Bebik, V. Gorbatenko, G. Shchedrova and other authors [10-13].

The purpose of this article is to examine the concept of civil society, particularly, in Ukraine, its functions and features. The goal will be achieved by implementing the following tasks: characteristics of civil society, welfare state and state of rights, identification of their interaction; identification of the state of political consciousness of civil society, trends in its development, interaction with other forms of social consciousness; analysis of theoretical and methodological aspects; analysis of problems that arise in the formation of political consciousness.

Paper main body. The idea of civil society with its roots reaches ancient Greece and Rome, finds its theoretical embodiment in the works of Aristotle, Cicero, other thinkers. Over time, there is understanding of civil society as a community of equal 
citizens, which does not depend on the state, but interacts with it for the sake of the common good. In the political sphere, civil society provides citizens for free participation in state and public affairs. The main subject of such a society is a person who freely develops individual and collective life, decentralized state power and local self-government, democratically solved socio-political problems based on well-balanced, consensus relations [14, p. 44-45].

The concept of "civil society" is differently interpreted in social sciences. Thus, Montesquieu, believing that society cannot exist without a government, distinguished by the state as a union of citizens and the state as a totality of officials [15, p. 262-263]. G. Spencer in accordance with his organic theory of society compared the state with a biological organism, considered it an aggregate of the management bodies, rule [16, p. 606]. His «hardware» idea later was used by Marxism.

It is known that in the primitive public society there were authorities. The functions of the ruling have not been identified in the life of the community yet. At the same the community was a source and bearer of power. Gradually there was a hi-

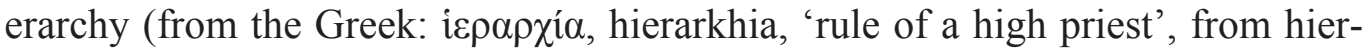
arches, 'president of sacred rites'; hieros - sacred and archia - power - division into higher and lower positions, ranks; the strict order of subordination of lower relative to the position or orient of individuals) of public administration, as a result of which ordinary communities were detached from the management of the community.

People's assembly is replaced by a military squad. The Council of Elders turn into more venerable and independent centers for making government decisions, only a part of which is made to formal approval of the assembly of communities. So gradually there was a public administration from the community. It was carried out by its separate institutions that the community was quite subordinate. In the future, due to Christian doctrine state and private began to distinguish between. Cursing an idea of a civil society as a means of limiting state power, restraining its relentless aspiration to the absolute, authoritarian [17, p. 75-76].

Implementation of the concept of «civil society» is associated with the idea of "natural rights of a person" which in the XVII century was fundamental in the formation and dissemination of legal consciousness, political and legal concepts, first of all the theory of "social contract". Thus, Hugo Grotius and Baruch (de) Spinoza by "natural rights" considered freedom of beliefs and thoughts, freedom of possession and use of property, equality of people among themselves, their security against arbitrariness, etc. [16, p. 607-608]. The distinction between civil society and the state launched Jean-Jacques Rousseau in the work "Discourse on the Origin and Basis of Inequality Among Men". Civil society, in his opinion, arose as a result of the formation of private property, and the state was created from his 
idea on the basis of a social contract. John Locke believed that people agreed to establish a state for the purpose of reliable provision of natural rights, equality and freedom, protection of person and property - the values of civil society [16, p. 392].

The aggregate of individuals who unlimited themselves with their natural rights formed, according to supporters of the contractual theory of the origin of the state, society in its "natural state" ("status naturalis"). This is the state of entirely freedom, which leads to "war of all against all". But under such conditions to have "right to everything", Thomas Hobbes asserted, means not actually not to be right on anything. In order to avoid threats that are necessarily arising in the natural state of society, people were forced to replace it to the state of Civic ("status civilis"). The transition from the natural state to civilization makes it possible to regulate laws and other rules of disordered relations [14, p. 44-45].

According to the theory of "social contract" people conclude an agreement and create a state that appears over society, alienates and focuses on part of their natural rights. So, there is a civil society, in contrast to the natural, pre-state is a state in which the state has existed. In the conventional theories of the state (J. Locke, Voltaire, J.-J. Rousseau), the citizenship state of society was perceived as an antipode of a natural state, but the authorities as a derivative of relations that dominate in a community society [18, p. 166-167].

The concept of civil society, its understanding as the realm of human freedom, which is outside the state regulation, is the generation of a liberal outlook. John Locke, called the "father of Liberalism", believed that the state is called primarily to protect personal freedom and property acquired by the work of people. It operates only in strictly outlined limits, which can lead to civil disobedience. People should have the right to resist arbitrariness of government, to resist it and even resort to force for its overthrow, when it directs its power to conqueror, usurpation, tyranny, or in the event of its collapse. Based on the recognition of self-value and priority of spontaneous human life, compared with managerial influence on it, enlightenments of the XVIII century (J. Locke, Ch. Montesquieu) proclaimed that the civil idea is higher and more significant than the idea of state. Georg Hegel distinguished civil society and political state. The scientist considered it indirectly through the work by the system of needs, based on the principle of domination of private property and the general formal equality of people. Niccolo Machiavelli, Montesquieu, Georg Hegel believed that society should be the object of influence of the state that can act quite independently. Political state wisdom is to take into account existing relations in society, thoughts and circumstances. Classical views on civil society have prepared a modern understanding of this phenomenon. Civil society is a society of citizens with a high level of economic, social, political, cultural and moral features, which jointly with the state forms developed legal relations. 
This is a community of all citizens, their free associations identified with social relations characterized by a high level of social consciousness and political culture that are outside the state regulation, but are guarded and guaranteed by it.

The formation of civil society is associated with the affirmation of the bourgeois system. It is impossible without the existence of law rule, but only the existence of a developed, stable civil society enables the formation of law rule. Highly developed civil society is the basis of a stable democratic political regime. Non-liberal (totalitarian, authoritarian) society is entirely or mainly subordinated to the state regulating, centralizing them. This way of interaction between the state and society is called statism that is characterized as a policy of is the spreaded state powers to all without exception. Its essence is to recognize the state as the most important and only factor in integrating society. In totalitarian societies the civil sphere is reduced to the minimum possible sizes, but never disappears entirely [19, p. 201].

Developed civil society involves the existence of a democratic law rule, which is intended to satisfy and protect the interests and rights of citizens. Prerequisites for civil society are: market economy with its own manner of ownership; multiplicity of independent political forces and parties; non-directively formed public opinion; free personality with a developed sense of self-dignity [20, p. 5-6]. Civil society is not only separate from the state society, autonomous sphere of social being, which is not a subject to direct control and regulation by the authorities, as well as a structured society. It provides freedom of associations of individuals by interests and preferences. Separate segments of the population form their groups, voluntary associations, which are designed to provide civilized relations with other subjects of co-existence in society. Therefore, civil society is a certain mechanism of an informal social partnership, which enables the implementation and balance of existing interests. Civil society in political science usually is considered as a social formation opposed to the state. It can be understood as pluralism and organization of interests regardless of the state.

Such a society is emancipated from the state, the realm of spontaneous selfexisting individuals and voluntarily formed associations and organizations of citizens protected by law on direct intervention and regulation by state authorities. It is embodied in the private life of citizens, the existence of a free market, unobstructed dissemination of spiritual, religious, moral, national values, etc. The basis of civil society is the life of individuals as private people, a set of freely established interpersonal ties (family, communal, economic, cultural, religious, etc.), diversity of interests, capabilities and methods of their expression and implementation.

The main features of civil society are the following: availability of democratic legal statehood; separated the state from the structure of society, which includes various voluntary associations of people; mutual responsibility of the state and 
citizens for the implementation of democratically accepted laws; self-government of individuals, voluntary organizations and associations of citizens; adequate free exchange of social system, the political system under which the state is derived from civil society and processes in it; approval of direct and diverse interests, the possibility of their expression and implementation; the possibility of providing genuine, real life, unlike the state - areas of conditional, formal life; a variety of forms of ownership (private, collective, co-operative, etc.), market economy; availability of free competition, relations of exchange of activities and its products between independent owners; direct communication of people; respect of civil rights, which are considered to be higher than state laws; access for all citizens to participate in state and public affairs; freedom of personality; pluralism of ideologies and political views, multiparty; pluralism, a totality of all non-political relations in society and diverse activities of people; presence of a developed social structure; diversity of social initiatives; developed civic political culture and consciousness; regulation of people's actions directly by the same people, primarily due to the norms of morality; control over the activities of public authorities [19, p. 201].

The existence of various controversial interests in the civil society, which it is not capable of satisfying, called for the state of the state as an embodiment, the implementation of general interest, as an institution, which responsibility is the guarantee and protection of human rights. In such a society there is a real property that is capable of being realized in the legal field.

If in a civil society the actions of people are due to their real needs and requirements of common sense, the state and performers of its will above all put the formal side of the case. Any event, meaningful and worthy for a person (birth, marriage, etc.), the state considers a real fact only after the fulfillment of proper formal procedures, documentary certification (drawing up a protocol, signing an act).

If civil society defends natural rights, economics, private life, sphere of freedom; the political society (state) relates to established laws, politics, state, public life and sphere of duty. The alternative features and values of the state and civil society do not mean their antagonism, but on the contrary, determines their mutual need. Without a state, a civil society is impossible, without civil society, a full legal state is impossible. They are interconnected aspects of one holistic person life, civilized social existence. Developed civil society creates conditions for free self-realization of individuals and their various associations and holds the state from suppressing individuals and society, making it more democratic and legal [21, p. 30].

The level of democracy in modern society is largely determined by the existence of independent associations system of sovereign individuals and freely established ties between them. Formed on pluralism, tolerance, liberalism (respect for the rights and freedoms of the person), such a society is able to confront both the statist 
tendencies by state and anarchism, to achieve optimal public governance. Open rivalry of public interest initiates a political process, promotes the implementation of general social interest $[17$, p. 82]. Therefore, for the democratization of society, the state reform is necessary not only for effective lawmaking, political and legal activity, but also the formation of civil society - the structuring of the community, awareness of the costs of their interests, the valuation of its own and foreign rights, dignity and freedom, the reverence of the rules and procedures of socio-political interaction.

In Ukraine today there is a gradual process of becoming a civil society, which is still very far from completion. Authorities of different levels have been already formed, but they still demonstrate the failure to bring the country from the system crisis, and therefore the dynamic process of citizens' alienation from the state, power and politicians is clear [22, p. 6-9]. Civil society is characterized by a system of the interests' representation of different groups of the population in the form of political parties that express the interests and formulate the political priorities of certain social groups. Today, political parties (registered more than 340) are not sufficiently contributing to the proper establishment of communication channels between the state and citizens.

The current level of self-organization of civil society in Ukraine is characterized by certain contradictions. On the one hand, optimism is provided by the growing willingness of people to defend their rights, unite in public organizations, increase civic activism, successful development and the introduction of various forms of public participation in public life. On the other hand, the effectiveness of civil society self-organization is hampered by the low level of citizen involvement in local development processes, activities of public organizations and local governments, passivity and paternalism of Ukrainian citizens on the ground, low representation of community members in self-government and public trust.

The trends in the transformation of the social structure of our state include the actual lack of middle class and significant progress in its formation, lumpenization of numerous groups of the population, the emergence of new owners, polarization of wealth and poverty, preserving the old nomenclature of its positions. More than 85 percent of the population of Ukraine occupy the position below the middle class and exists in extreme uncertainty and unpredictability. Due to the formation of the middle class, the stratification of society on the rich and poor prevails the principle of strength, and not the principle of law, although the intention of the legal state is declared everywhere.

Factors of the formation in Ukraine of civil society are: free and alternative political elections, referendums; independent (primarily from the authorities) media; development of local self-government; political parties capable of representing group interests; availability of market relations and economic pluralism. To 
strengthen the processes of self-organization, it is necessary to promote the increase of analytical capabilities in society, there should be an expanded discourse with the involvement of a wide range of civil society experts, increase public participation in reforming the country [23, p. 65-67].

The welfare state acquires special significance in modern conditions. The welfare state is a state that seeks to ensure every citizen of decent living conditions, social security, complicity in the management of production, and in the ideal of approximately the same vital chances, opportunities for self-realization of personality [24, p. 213-214]. The term "welfare state" was introduced in 1850 by German scientist-lawyer Lorenz von Stein [25, p. 48-49]. However, his active theoretical development and practical embodiment began in Germany in the second half of the XX century. The theoretical principles of the social state are highlighted in the works of G. Richter (Germany), A. Brown (USA), M. Boretti (France).

The experience of developed countries convincingly indicates that the origin and formation of a social state are not spontaneously, but on the basis of purposeful state policy. The transition to the state of the specified type is possible only with the implementation of a systematic strategy of reforms, which binds to a holistic complex of movement to a socio-market economy, civil society, a legal state with a purposeful formation of social institutions. The content of the welfare state is manifested in the promotion of such elements of modern society as a social market economy, social democracy, social ethics.

The principles of solidarity and subsidy belong to the most important principles of maintaining the harmonious relationship between citizens and the state, which contribute to the functioning of the state mechanism with social content. Solidarity involves unity and purposeful association of various groups and segments of society around the main objectives and values, both current and long-term perspective. The idea of solidarity is based on the help of the stronger to the weak, in mutual support and responsibilities of citizens in front of the state and one before one.

The principle of subsidy received an expanded submission in the social doctrine of the Catholic Church and acquired socio-state content in the practice of state construction of Federal Republic of Germany and other developed West countries. According to this principle, the superior echelons of the management are performed only those tasks that are not possible to be lower than the ranks and are intended to help the latter in supporting their independence and their own responsibility. Initiated by the state, the subsidiary contributes to overcoming consumer psychology in citizens and their associations, functional overload of the state, uncontrolled growth of bureaucracy, and also stimulates group and personal population initiative [26]. It should be taken into account that the social state in each country is formed, based on the specifics of national, historical, socio-political, geographical conditions and traditions of coexistence within a particular society. Accordingly, a model that 
allows you to find your own, optimal path to the social state is created.

The theory of rights' state originates from antiquity. The ancient Greek philosopher Plato wrote that statehood is possible only where fair laws are dominated, «where the law is the owner over the rulers, and they are slaves». Since the new time, the theory of the rights' state was supplemented by direct appeal to the idea of human rights. Advanced era thinkers of the formation of capitalism in the XVII-XVIII centuries formulated the principle of separation of powers, laid down the basis of the theory of a state of rights. Thus, the German philosopher I. Kant believed that the state provides the triumph of law and is subordinated to its requirements. Another German philosopher M. Weber formulated the principles of such a state [27, p. 87]. Rights' state is characterized by: the rule of law and its domination in society; equality before the law itself, all its authorities, public organizations, officials and citizens; the supremacy of representative authorities, their openness and publicity, the absence of any dictatorship; separation of powers into three branches: a legislature, an executive, and a judiciary, which creates a system of mutual restraint and mutual opposition of branches of government; a guarantee of the rights and freedoms of a person within the limits of legality, mutual responsibility of the state, associations of citizens and individuals; high level of public structures, the possibility of public associations and individuals to participate in the management of society; observance of the principles of general, direct, equal suffrage; control of public authorities by society, citizens and their organizations; responsibility of the state to the world community of legal states; organic connection of the rights and freedoms of citizens with their responsibilities, duties, laws, self-control, self-consciousness, legal culture [24, p. 211-212]. In addition to strict adherence to laws, society provides for another fundamental requirement - observance of generally accepted norms of morality. The right and moral have always been the factors of human existence and humanism [28, p. 11].

Conclusions. There are no final words on civil society, because civil society is constantly being reinterpreted and recreated. Civil society can be understood as the «third sector» of society, distinct from government and business, and including the family and the private sphere. By other authors, civil society is used in the sense of 1) the aggregate of non-governmental organizations and institutions that manifest interests and will of citizens or 2) individuals and organizations in a society which are independent of the government. It is protected by law from direct interference by public authorities. In civil society there are qualitatively new relations between society and nature, between society and the state, between society and the individual, between the individual and the state. The development of civil society is a guarantor against authoritarianism and totalitarianism. Civil society exists in contradictory unity with the state. Under a democratic regime, it closely touches and interacts in passive and active opposition to the regime. The 
conditions for the functioning of civil society are: the presence in society of a developed social structure that reflects the different interests of the social community, the ownership of property by every citizen, personal or collective right to dispose of it at its discretion; sufficiently high level of social, intellectual, psychological development of members of society, ability to full self-activity. At present, humanity is more aware of the essence of a highly developed civil society; the current level of development of civilization requires the expansion of the boundaries of civil society, the emergence of a new, modern society adequate to it. In particular, there is a possibility of parallel growth of the role and activity of the state and civil society, their interaction and interaction.

Prospects for further research. Building a democratic, constitutional and welfare state in Ukraine is directly related to the formation of civil society. In independent Ukraine, the formation of civil society is a priority. In the current conditions of Ukrainian reality, civil society institutions are only being formed, due to which they cannot fully control state power. However, there are already tendencies of participation and growing role of civil society institutions, which are becoming stronger, in the mechanism of realization of constitutional rights and freedoms of man and citizen in Ukraine. At the same time, the institutions of civil society should not completely absorb the state, replacing the implementation of its basic functions by non-state structures. Without the effective implementation of its basic functions by the state, it is impossible to create and develop a full-fledged civil society in Ukraine.

\section{REFERENCES}

1. Denisenko, V. M., Blikhar, V. S., Uhryn, L. Ya., et al. (2015). Teoriia polityky [Policy Theory]. Lviv: Liha-Pres [in Ukrainian].

2. Egholm, L., \& Kaspersen, L. B. (Eds.). (2021). Civil Society: Between Concepts and Empirical Grounds. Abingdon, Oxon; New York, NY: Routledge.

3. Fine, G. A. (2021). The Hinge: Civil Society, Group Cultures, and the Power of Local Commitments. Chicago: University of Chicago Press.

4. Herasina, L. (2008). Hromadianske suspilstvo i kolizii v protsesi realizatsii politychnoi vlady [Civil Society and Conflicts in the Process of Political Implementation Authorities]. Visnyk Akadimii pravovykh nauk Ukrainy - Bulletin of the Academy of Legal Sciences of Ukraine, 54(3), 43-51 [in Ukrainian].

5. Korniievskyi, O. A., Tyshchenko, Yu. A., \& Yablonskyi, V. M. (Eds.). (2020). Hromadianske suspilstvo Ukrainy: polityka spryiannia ta zaluchennia, vyklyky ta transformatsii [Civil Society of Ukraine: Policy of Promotion and Involvement, Challenges and Transformations: Analytical Report]. Kyiv: NISD [in Ukrainian].

6. Bader, M. (2019). Hromadianske suspilstvo vs. koruptsiia v Ukraini [Civil Society vs. Corruption in Ukraine]. Nesterenko, O. V. (Ed.). Kyiv: Dukh i Litera [in Ukrainian]. 
7. Stepanenko, V. P. (2015). Hromadianske suspilstvo: dyskursy i praktyky [Civil Society: Discourses and Practices]. Kyiv: In-t sotsiolohii NAN Ukrainy [in Ukrainian].

8. Trebin, M. P. (2013). Suchasnyi stan hromadianskoho suspilstva v Ukraini: problemy i perspektyvy [The Current State of Civil Society in Ukraine: Problems and Prospects]. Ukrainskyi sotsium - Ukrainian Society, 47(4), 161-174 [in Ukrainian].

9. Trebin, M. P. (2014). Rozvytok hromadianskoho suspilstva v Ukraini v konteksti yevrointehratsii [Development of civil society in Ukraine in the context of European integration]. Ukrainskyi sotsium - Ukrainian society, 48(1), 106-118 [in Ukrainian].

10. Babkina, O. V., Basaliukov, V. V., Bebik, V. M., et al. (2003). Derzhava i hromadianske suspilstvo: komunikatsiini aspekty i protyrichchia tretoho stolittia [State and Civil Society: Communication Aspects and Contradictions of the Third Century]. PR vorhanakh derzhavnoi vlady ta mistsevoho samovriaduvannia [PR in Public Authorities and Local Self-Government] (pp. 8-24). Bebik, V. M., \& Kunitsyn, S. V. (Eds.). Kyiv; Symferopol: MAUP [in Ukrainian].

11. Bebyk, V. (2006). Hlobalne hromadianske suspilstvo : teoriia, metodolohiia, menedzhment [Global Civil Society: Theory, Methodology, Management]. Politychnyi menedzhment - Political Management, 17(2), 140-147 [in Ukrainian].

12. Shchedrova, H. P. (2009). Hromadianske suspilstvo ta politychna kultura: teoretychnyi i prykladnyi aspekty [Civil Society and Political Culture: Theoretical and Applied Aspects]. Luhansk: Elton-2 [in Ukrainian].

13. Shchedrova, H. P. (2016). Samoorhanizatsiia hromadianskoho suspilstva: teoretychni zasady i praktychni realii [Self-Organization of Civil Society: Theoretical Principles and Practical Realities]. Hileia: naukovyi visnyk - Gileya: Scientific Herald, 114, 341-345 [in Ukrainian].

14. Babkina, O. V., \& Horbatenko, V. P. (Eds.). (2008). Politolohiia [Politology] (3rd ed.). Kyiv: Akademiia [in Ukrainian].

15. Alieksieienko, I. V., Andrushchenko, T. V., Babkina, O. V., et al. (2016). Istoriia politychnoi dumky [History of Political Thought]. Khoma, N. M. (Ed.). Lviv: "Novyi Svit - 2000" [in Ukrainian].

16. Denysenko, V. M., Uhryn, L. Ya., Shypunov, H. V., et al. (2014). Istoriia politychnoi dumky [History of Political Thought]. Khoma, N. M. (Ed.). Lviv: "Novyi Svit-2000" [in Ukrainian].

17. Riabov, S. H. (1996). Politolohichna teoriia derzhavy [Political Science Theory of the State]. Kyiv: Tandem [in Ukrainian].

18. Trebin, M. P., Herasina, L. M., Polishchuk, I. O., et al. (2013). Politolohiia [Politology]. Trebin, M. P. (Ed.). Kharkiv: Pravo [in Ukrainian].

19. Bebyk, V. M. (2000). Bazovi zasady politolohii: istoriia, teoriia, metodolohiia, praktyka [Basic Principles of Political Science: History, Theory, Methodology, Practice]. Kyiv: MAUP [in Ukrainian].

20. Vasyliev, H. Yu., Vodnik, V. D., Volianska, O. V., et al. (2013). Hromadianske suspilstvo: politychni ta sotsialno-pravovi problemy rozvytku [Civil Society: Political and Socio-Legal Problems of Development]. Trebin, M. P. (Ed.). Kharkiv: Pravo [in Ukrainian]. 
21. Havronska, T. V. (2019). Poniattia protsesiv rozvytku hromadianskoho suspilstva pry demokratychnykh peretvorenniakh u derzhavi [The Concept of the Processes of Development of Civil Society in Democratic Transformations in the State]. Naukovyi chasopys Natsionalnoho pedahohichnoho universytetu imeni M. P. Drahomanova. Seriia 18: Pravo - Scientific Journal of the M. P. Drahomanov National Pedagogical University. Series 18: Law, 34, 30-36 [in Ukrainian].

22. Panfilov, O. Yu. (Ed.). (2013). Sotsialno-humanitarna sfera Ukrainy pered hlobalnymy vyklykamy suchasnosti [Social and Humanitarian Sphere of Ukraine in the Face of Global Challenges of Today]. Kharkiv: Vydavnytstvo "Inzhek" [in Ukrainian].

23. Horak, H., Finin, H. (2008). Hromadianske suspilstvo yak intehrator osobystisnykh nachal [Civil society as an integrator of personal principles]. Filosofska dumkaPhilosophical Thought, (3), 62-73 [in Ukrainian].

24. Trebin, M. P. (Ed.). (2015). Politolohichnyi entsyklopedychnyi slovnyk [Political Science Encyclopedic Dictionary]. Herasina, L. M., Pohribna, V. L., Polishchuk, I. O., et al. (Comps.). Kharkiv: Pravo [in Ukrainian].

25. Korniienko, V. (2001). Realizatsiia idealu sotsialno-pravovoi derzhavy v ukrainskomu suspilstvi [Realization of the Ideal of the Social and Legal State in the Ukrainian Society]. Pravo Ukrainy - Law of Ukraine, (2), 47-53 [in Ukrainian].

26. Babkin, V. D. (1999). Sotsiavlna derzhava ta zakhyst prav liudyny [Welfare State and Protection of Human Rights]. Pravova derzhava-Constitutional State, 9, 3-11. Kyiv: In Yure [in Ukrainian].

27. Levenets, Yu., \& Shapoval, Yu. (Eds.). (2011). Politychna entsyklopediia [Political Encyclopedia]. Kyiv: Parlamentske vydavnytstvo [in Ukrainian].

28. Panfilov, O. Yu. (Ed.). (2019). Sotsialno-humanitarna sfera Ukrainy v suchasnykh dyskursakh [Social and Humanitarian Sphere of Ukraine in Modern Discourses]. Kharkiv: KhIF KNTEU [in Ukrainian].

Марціхів Христина Романівна, кандидат педагогічних наук, доцент кафедри іноземних мов, Національний університет «Львівська політехніка», Україна

Горбачова Лілія Свгенівна, студентка, Національний університет «Львівська політехніка», Україна

\section{КОНЦЕПЦІЯ ГРОМАДЯНСЬКОГО СУСПІЛЬСТВА, ЙОГО ФОРМУВАННЯ В УКРАЇНІ, ФУНКЦІЇ ТА ОСОБЛИВОСТІ}

Подано визначення поняття «громадянське суспільство» в сучасній політології. Проаналізовано актуальність його теоретичних і практичних аспектів, що спричинено очевидним підвищенням ролі пересічних громадян та їх добровільних об'єднань у всіх сферах життєдіяльності людського суспільства: економічній, політичній, соиіальній, духовній. Досліджено широко відомі успіхи громадських організацій 
і рухів людей доброї волі в галузі розрядки міжнародної напруженості, у наданні допомоги народам, що постраждали від стихійних лих, катастроф та інших сочіальних негараздів. Встановлено, що в основі перемог - розвиток діяльності громадянського суспільства, висока активність громадян та їх добровільних об'єднань. Це досяжне тільки в достатньо розвиненому громадянському суспільстві. Доведено, що успіхи приходять там, де підвищується ділова активність громадян і створюваних ними недержавних структур, обмежується державне втручання в економічне, сочіальне і духовне життя, тобто там, де розвивається $і$ вдосконалюється громадянське суспільство. Осмислено теоретичний і прикладний аспекти феномену громадянського суспільства завдяки теоретичному аналізу концепиії громадянського суспільства в історії сочіально-філософської та політологічної думки, починаючи з Платона й Аристотеля та закінчуючи поглядами сучасних дослідників. Підкреслено, що громадянське суспільство - тип суспільного устрою, відмітна ознака якого - реальна багатосуб 'єктність економічного, соціального, культурного і політичного життя. Проаналізовано формування та розвиток громадянського суспільства в Украӥні за роки незалежності. Доведено, щзо становлення громадянського суспільства виявляється у формуванні його інститутів - добровільних громадських об'єднань, громадських рухів, професійних спілок, незалежних засобів масової інформаџії, громадської думки як сочіального інституту, виборах та референдумах як засобах громадського волевиявлення і захисту інтересів, залежних від громадськості елементів судової і правоохоронної систем тощо. Обтрунтовано особливості взаємодії громадянського суспільства і правової держави.

Ключові слова: громадянське суспільство, концепція громадянського суспільства, державна влада, політична партія, сочіальна держава, правова держава.

Марцихив Кристина Романовна, кандидат педагогических наук, доцент кафедры иностранных языков, Национальный университет «Львовская политехника», Украина

Горбачева Лилия Евгеньевна, студентка,

Национальный университет «Львовская политехника», Украина

\section{КОНЦЕПЦИЯ ГРАЖДАНСКОГО ОБЩЕСТВА, ЕГО ФОРМИРОВАНИЕ В УКРАИНЕ, ФУНКЦИИ И ОСОБЕННОСТИ}

Дано определение понятия «гражданское общество» в современной политологии. Проанализирована актуальность его теоретических и практических аспектов, вызванная очевидным повышением роли рядовых граждан и их добровольных объединений во всех сферах жизнедеятельности человеческого общества: экономической, политической, социальной, духовной. Исследованы широко известные успехи общественных организаџий и движений людей доброй воли в области разрядки международной напряженности, в оказании помощчи народам, пострадавщим 
от стихийных бедствий, катастроф и других сочиальных проблем. Установлено, что в основе побед - развитие деятельности гражданского общества, высокая активность граждан и их добровольных объединений. Это достижсимо только в достаточно развитом гражданском обществе. Доказано, что успехи приходят там, где повышается деловая активность граждан и создаваемых ими негосударственных структур, ограничивается государственное вмешательство в экономическую, сочиальную и духовную жизнь, т. е. там, где развивается и совершенствуется гражданское общество. Осмыслены теоретические и прикладные аспекты феномена гражданского общества благодаря теоретическому анализу концепиии гражданского общества в истории сочиально-философской и политологической мысли, начиная с Платона и Аристотеля и заканчивая взглядами современных исследователей. Подчеркнуто, что гражданское общество - тип общественного устройства, отличительный признак которого - реальная многосубъектность экономической, сочиальной, культурной и политической жизни. Проанализированьь прочессы формирования и развития гражданского общества в Украине за годы независимости. Доказано, что становление гражданского общества проявляется в формировании его институтов - добровольных общественных объединений, общественных движений, профсоюзов, независимых средств массовой информаиии, общественного мнения как социального института, выборах и референдумах как средствах общественного волеизъявления и защиты интересов, зависимых от общественности элементов судебной и правоохранительной систем и тому подобное. Обоснованы особенности взаимодействия гражданского общества и правового государства.

Ключевые слова: гражданское общество, конщепиия гражданского общества, государственная власть, политическая партия, сочиальное государство, правовое государство.

\section{$\operatorname{son}$}

